\title{
Obstetric practices in planned home births assisted in Brazil*
}

\author{
Práticas obstétricas nos partos domiciliares planejados assistidos no Brasil \\ Prácticas obstétricas en los partos domiciliarios planificados asistidos en Brasil
}

Joyce Green Koettker', Odaléa Maria Bruggemann², Paulo Fontoura Freita ${ }^{3}$, Maria Luiza Gonzalez Riesco ${ }^{4}$, Roberta Costa ${ }^{5}$

How to cite this article:

Koettker JG, Bruggemann OM, Freitas PF, Riesco MLG, Costa R. Obstetric practices in planned home births assisted in Brazil. Rev Esc Enferm USP. 2018;52:e03371. DOI: http://dx.doi.org/10.1590/S1980-220X2017034003371

\author{
* Extracted from the thesis: "Parto domiciliar \\ planejado assistido por profissional qualificado \\ nas Regiões Nordeste, Centro-Oeste, \\ Sudeste e Sul do Brasil", Universidade \\ Federal de Santa Catarina, 2016. \\ 1 Equipe Hanami, O Florescer da Vida, Parto \\ Domiciliar Planejado, Florianópolis, SC, Brazil. \\ 2 Universidade Federal de Santa \\ Catarina, Programa de Pós-Graduação \\ Enfermagem, Florianópolis, SC, Brazil. \\ ${ }^{3}$ Universidade Federal de Santa Catarina, \\ Hospital Universitário, Serviço de Saúde \\ Pública, Florianópolis, SC, Brazil. \\ ${ }^{4}$ Universidade de São Paulo, Escola \\ de Enfermagem, Departamento de \\ Enfermagem Materno Infantil e \\ Psiquiátrica, São Paulo, SP, Brazil. \\ 5 Universidade Federal de Santa Catarina, \\ Departamento de Enfermagem, Programa \\ de Pós-Graduação em Enfermagem, \\ Florianópolis, SC, Brazil.
}

\begin{abstract}
Objective: To describe obstetric practices in planned home births, assisted by qualified professionals in Brazil. Method: This is a descriptive study, with data collected in an online bank maintained by 49 professionals from December 2014 to November 2015, in which the target population was women and newborns assisted in home births. Data were analyzed through descriptive statistics. Results: A total of 667 women and 665 newborns were included. Most of the women gave birth at home (84.4\%), in a nonlithotomic position (99.1\%); none underwent episiotomy; 32.3\% had intact perineum; and 37.8\% had firstdegree lacerations, some underwent amniotomy (5.4\%), oxytocin administration (0.4\%), and Kristeller's maneuver $(0.2 \%) ; 80.8 \%$ of the women with a previous cesarean section had home birth. The rate of transfer of parturients was $15.6 \%$, of puerperal women was $1.9 \%$, and of neonates $1.6 \%$. The rate of cesarean section in the parturients that started labor at home was $9.0 \%$. Conclusion: The obstetric practices taken are consistent with the scientific evidence; however, unnecessary interventions are still performed. The rates of cesarean sections and maternal and neonatal transfers are low. Home can be a place of birth option for women seeking a physiological delivery.
\end{abstract}

\section{DESCRIPTORS}

Home Childbirth; Humanizing Delivery; Obstetric Nursing; Observational Study. 


\section{INTRODUCTION}

Brazil does not have data regarding the care provided to planned home births (PHB), because the Live Birth Information System (SINASC - Sistema de Informação sobre Nascido Vivo) encompasses all births taking place out of the hospital environment, regardless of whether they were planned to occur at home, and of which professional provided care.

In developed countries, the prevalence of planned home births assisted by a qualified professional varies: $11.3 \%$ in New Zealand ${ }^{(1)}, 2.8 \%$ in England ${ }^{(2)}$, and less than 1\% in Australia ${ }^{(3)}$. However, in the Netherlands, $62.7 \%$ of women plan childbirth at home ${ }^{(4)}$.

According to the World Health Organization (WHO) and the Brazilian Ministry of Health, obstetric nurses, midwives, and physicians are qualified professionals to assist vaginal delivery ${ }^{(5-6)}$.

In Brazil, obstetric care practices in health institutions are not always scientific evidence-based, as shown in the survey Birth in Brazil ${ }^{(7)}$. Differently from the Brazilian hospital context, several international studies indicate that $\mathrm{PHB}$ care is not interventionist ${ }^{(1,3-4)}$.

Care practices developed in the home environment are described in some quantitative studies that analyzed small samples (from 70 to 212 women) ${ }^{(8-10)}$. These studies revealed lower rates of interventions, such as amniotomy and episiotomy, when compared to hospital rates, and there is a greater adoption of good practices, such as freedom of deambulation, movement and eating, participation of partners, skin-to-skin contact, breastfeeding stimulation, freedom of choice on the type of position at delivery, and high rates of vaginal delivery after cesarean sections.

In the Brazilian reality, several professionals have been assisting childbirth at home. However, due to the scarcity of data on this type of care, and the need to know the procedures performed and the behaviors followed in this context, the following research question arises: Which are the obstetric practices performed at home, since the number of women who opt for home birth is increasing? The indicators from this study will provide data to deepen the discussion about delivery and birth care in a non-institutional environment assisted by qualified professionals.

Therefore, the objective of this study was to describe obstetric practices in planned home births, assisted by qualified professionals, in Brazil.

\section{METHOD}

This is a descriptive study, with prospective data collection, in which the target population was women and newborns (NB) assisted at planned home births by qualified professionals, in the Northeast, Center-west, Southeast and South regions of Brazil, regardless of the place of birth (home or hospital) outcome. The professionals were identified and contacted in at least two states in each region. Thus, professionals who assisted births in the following states participated in the study: Alagoas, Bahia, Ceará, Pernambuco, Goiás, Mato Grosso, Minas Gerais, Rio de
Janeiro, São Paulo, Paraná, Rio Grande do Sul, and Santa Catarina, totaling 12 states, plus the Federal District. The North region was excluded, because a qualified professional who assisted deliveries at home was found in only one state.

The professionals were identified through personal contact in scientific events of the obstetric area, Internet social networks, and the virtual snowball sampling technique. This technique facilitates the selection of participants; however, with its use, the people indicated are those most visible in the population, which generates a limitation and a possible bias.

Professionals' inclusion criteria were: to have a college degree, and to be registered in the professional council and legally qualified to assist vaginal childbirth, according to the legislation of the professional practice. Thus, obstetric nurses, midwives and physicians were invited to participate.

A total of 123 professionals were contacted; however, some were not eligible or did not wish to participate. Thus, initially, 94 professionals (obstetric nurses, midwives and physicians) agreed to participate in the research. To ensure ethical procedures, an informed consent form was sent to the professionals and also to the women who would be assisted by them, along with a letter of instructions and previously stamped envelopes for returning the forms. It should be highlighted that the professionals were oriented to include all the women assisted during the period of data collection in the database. After this stage, some gave up, with 49 professionals staying in the study (37 obstetric nurses, seven obstetric physicians, three midwives, and two general practitioners) representing $36 \mathrm{PHB}$ care teams in the Northeast, Center-west, Southeast and Southern regions of Brazil. Each team elected one professional responsible for completing the information in the database.

The mean age of the professionals who assisted the women was 39.1 years $(\mathrm{SD}=8.7)$, most of them being female (94.2\%), with a mean time of service in PHB of 6.7 years $(\mathrm{SD}=4.9) ; 58.9 \%$ did not assist childbirth in public or private health institutions. The average time since graduation of obstetric nurses and physicians was 12.7 years $(\mathrm{SD}=8.0)$, and of the midwives and general practitioners, 7.1 years (SD $=8.5$ ). Most deliveries were assisted by an obstetric nurse (74.8\%), followed by an obstetric physician (20.2\%), midwife (3.8\%) and general practitioner (1.2\%), and the professionals assisted births in a team with two or three people (82.1\%). The composition of these teams was diverse, being generally formed by obstetric nurses, some also had the participation of a midwife and an obstetric physician and, occasionally, other professionals (general nurse, nursing technician, general practitioner and neonatologist, and psychologist) and doulas. The teams that had the obstetric physician as the reference of care usually had an obstetric nurse, an obstetric physician, and possibly other professionals (neonatologist, nursing technician and another general practitioner) and a doula. When the team consisted of midwives, occasionally there was the participation of an obstetric nurse, an obstetric physician and a doula.

The professionals were guided about the inclusion and exclusion criteria, because they were responsible for the selection of eligible women and their NB. The criteria for inclusion 
of the women were: having been assisted at home during labor, during delivery or in both clinical periods, in a planned manner, by a qualified and legally certified professional to assist vaginal delivery. The criteria for inclusion of the newborns were: being born at home or in a health institution, after transfer of the parturient, with those born with congenital malformation, regardless of the place of birth being excluded.

Thus, the sample consisted of women assisted at home during labor or delivery, in a planned manner, and of their $\mathrm{NB}$, during the data collection period, that is, from December 2014 to November 2015, totaling 667 women and 665 newborns (two were excluded due to congenital malformation).

Data collection was possible due to the creation of an online database in the Google Docs system, which was made available to the 49 professionals, with the use of a password and a personal identification number. At the end of the assistance, the professionals registered their personal data, as well as the data of the woman and the NB. The entry of the data in the database was monitored weekly by the main researcher, in order to identify errors of registration or typing, absence of assistance and withdrawal from participation, and also to be available to clarify questions.

The data were transferred to the Excel software version 2008 and grouped by professional. Data were then sent to each professional for verification of duplicity, or lack of record of any assistance.

Sociodemographic and obstetric conditions were collected through the variables: age; level of education; region of residence; number of prenatal visits; previous deliveries; and gestational age at the time of delivery, through ultrasonography. Obstetric practices related to labor and delivery were measured using the following variables: amniotomy; use of oxytocin in labor and delivery; instrumental delivery; transfer of parturient or puerperal women to a healthcare institution; position at delivery (out of the water: sitting/semi-sitting, squatting, all fours, kneeling, upright, Sims, gynecological, McRoberts, and in the hammock; in the pool: sitting/semisitting, squatting, all fours, kneeling, upright, and Sims; in the shower: in any position); Kristeller's maneuver; episiotomy; degree of perineal laceration (1st degree - mucosal lesion, 2nd degree - lesion of the perineal muscles without reaching the anal sphincter; 3rd degree - perineal lesion involving the anal sphincter complex; 4th degree - lesion of the perineum surrounding the anal internal and external sphincter complex, and anal epithelium); need for laceration suture; transfer of the NB to a health institution.

For data quality control, $10 \%$ of the women were contacted by telephone, and all of them confirmed their participation in the research and some information about delivery and birth.

The data were analyzed using descriptive statistics, with absolute and relative frequency values for the categorical variables and with mean and standard deviation (SD) for the continuous variables.

All ethical aspects involving the research are in accordance with Resolution no. 466 of December 12, 2012. The research protocol was approved in November 2014 under report no. 865.451 and CAAE no. 33727314.2.0000.0121.

\section{RESULTS}

The results on the characteristics of the women assisted at home, as well as the obstetric practices in labor and delivery, were extracted from the information provided by the 49 professionals who participated in the study, that is, data were collected from their perspective and the records made by them.

Of the 667 women analyzed, most of them had a high level of education, resided in the Southeast and South regions of the country, had more than six prenatal consultations, and were primiparous, with full term gestation. The mean age reached 30 years (Table 1 ).

Table 1 - Sociodemographic and obstetric characteristics of women assisted at home - Northeast, Center-west, Southeast and South regions, Brazil, 2015

\begin{tabular}{|c|c|c|}
\hline Variables & $\mathbf{n}$ & $\%$ \\
\hline Age (mean, in years) & \multicolumn{2}{|c|}{$30.9(\mathrm{SD}=4.5)$} \\
\hline \multicolumn{3}{|l|}{ Level of education $(n=660)$} \\
\hline Secondary school & 8 & 1.2 \\
\hline High school & 103 & 15.6 \\
\hline Graduate studies & 433 & 65.6 \\
\hline Postgraduate studies & 116 & 17.6 \\
\hline \multicolumn{3}{|l|}{ Region of residence } \\
\hline Southeast & 271 & 40.7 \\
\hline South & 169 & 25.3 \\
\hline Northeast & 122 & 18.3 \\
\hline Center-west & 105 & 15.7 \\
\hline \multicolumn{3}{|l|}{ Prenatal consultations } \\
\hline$\leq 6$ & 73 & 10.9 \\
\hline$>6$ & 594 & 89.1 \\
\hline \multicolumn{3}{|l|}{ Previous births } \\
\hline None & 372 & 55.8 \\
\hline$\geq 1$ vaginal delivery ${ }^{*}$ & 191 & 28.6 \\
\hline$\geq 1$ C-section & 79 & 11.9 \\
\hline$\geq 1$ vaginal deliveryt and C-section & 25 & 3.7 \\
\hline Gestational age (mean, in weeks) $(n=653)$ & \multicolumn{2}{|c|}{$39^{5 / 7}(\mathrm{SD}=1.2)$} \\
\hline$<37 \ddagger$ & 4 & 0.6 \\
\hline $37-39$ & 297 & 45.5 \\
\hline $40-41$ & 324 & 49.6 \\
\hline$\geq 42$ & 28 & 4.3 \\
\hline
\end{tabular}

*Eight forceps deliveries and one vacuum extraction. ${ }^{\dagger}$ Three forceps deliveries. ${ }^{\ddagger}$ All with gestational age of 36 weeks and 6 days. Note: $(n=667)$.

Of the women whose labor started at home $(\mathrm{N}=667)$, $563(84.4 \%)$ gave birth at home, of which eight (1.4\%) gave birth before the professional arrived. Some underwent amniotomy $(5.4 \%)$ and vaginal delivery using a vacuum extractor $(0.5 \%)$, only three received oxytocin during labor or delivery, and one underwent Kristeller's maneuver due to fetal heart rate deceleration in the expulsive period. About one-sixth of the parturients needed to be transferred to a health institution, and the transfer rate of puerperal women and newborns was below 2\% (Table 2). 
Most transferred women were referred to a cesarean section (57.7\%), with $42.3 \%$ having a vaginal delivery (6.8\% with forceps or vacuum, $34 \%$ with analgesia, and $15.9 \%$ with analgesia and forceps or vacuum) (data not shown in the Table).

Regarding the perineal trauma, no woman underwent episiotomy, $37.8 \%$ had $1^{\text {st }}$ degree laceration; $28.5 \%, 2^{\text {nd }}$ degree laceration; $0.7 \%, 3^{\text {rd }}$ degree laceration; and one had $4^{\text {th }}$ degree laceration $(0.2 \%)$. Only $57.8 \%$ of the lacerations were sutured (data not shown in Table).

Table 2 - Obstetric practices at labor and delivery of women assisted at home - Northeast, Center-west, Southeast and South regions, Brazil, 2015

\begin{tabular}{lrr}
\hline Obstetric practices & $\mathrm{n}$ & $\%$ \\
\hline Amniotomy & 36 & 5.4 \\
Amniotic bag integrity until the expulsive period & 117 & 17.5 \\
Oxytocin at labor & 1 & 0.1 \\
Oxytocin at delivery $(\mathrm{n}=563)$ & 2 & 0.3 \\
Vacuum extraction vaginal delivery ${ }^{*}(\mathrm{n}=563)$ & 3 & 0.5 \\
Kristeller's maneuver $(\mathrm{n}=563)$ & 1 & 0.2 \\
Intact perineum $(\mathrm{n}=555)$ & 182 & 32.8 \\
Parturient transfer & 104 & 15.6 \\
Puerperal women transfer $(\mathrm{n}=563)$ & 11 & 1.9 \\
NB transfer $(\mathrm{n}=561)$ & 9 & 1.6 \\
\hline
\end{tabular}

*Assisted by an obstetric physician.

Note: $(\mathrm{n}=667)$.

Birth positions adopted by the women are presented in Table 3. Almost all of the women gave birth in verticalized positions, with less than a half choosing water birth.

Table 3 - Birth positions adopted by women giving birth in the water and out of water at home - Northeast, Center-west, Southeast and South regions, Brazil, 2015

\begin{tabular}{lrr}
\hline Birth position $^{*}$ & $\mathbf{n}$ & \% \\
\hline Out of water & $\mathbf{2 9 2}$ & $\mathbf{5 2 . 6}$ \\
Birthing stool & 130 & 23.42 \\
All fours/genupectoral & 49 & 8.8 \\
Supported squatting & 33 & 6.0 \\
Sitting/semi-sitting & 24 & 4.3 \\
Upright & 20 & 3.6 \\
Kneeling & 17 & 3.1 \\
Sims & 14 & 2.5 \\
Gynecological & 3 & 0.5 \\
McRoberts & 1 & 0.2 \\
In the hammock & 1 & 0.2 \\
\hline In the water (pool) & $\mathbf{2 3 3}$ & $\mathbf{4 2 . 0}$ \\
Sitting/semi-sitting & 119 & 21.4 \\
All fours/genupectoral & 52 & 9.4 \\
Squatting & 51 & 9.2 \\
Sims & 6 & 1.1 \\
Kneeling & 3 & 0.5 \\
Upright & 1 & 0.2 \\
Birthing stool & 5.2 \\
\hline In the shower in any position & 5.4 \\
\hline
\end{tabular}

*Eight birth positions were not mentioned.

Note: $(\mathrm{n}=563)$.
It should be noted that, of the 79 women with a previous cesarean section that started labor at home, $75.9 \%$ had a vaginal birth at home. Of the women who had a previous cesarean section, but also a previous vaginal delivery, almost all had a PHB (96.0\%) (Table 4). Among those who gave birth in the hospital, $28.6 \%$ had forceps delivery, and $85.7 \%$ received analgesia (data not shown in Table).

Table 4 - Home follow-up of women with a previous C-section according to the delivery place and current type - Northeast, Center-west, Southeast and South regions, Brazil, 2015

\begin{tabular}{lccc}
\hline \multirow{2}{*}{ Previous delivery } & $\begin{array}{c}\text { Current delivery } \\
\text { at home }\end{array}$ & \multicolumn{2}{c}{$\begin{array}{c}\text { Current delivery in the } \\
\text { hospital }\end{array}$} \\
\cline { 2 - 4 } & $\mathbf{n}(\%)$ & $\mathbf{n ~ ( \% )}$ & $\mathbf{n}(\%)$ \\
\hline $\begin{array}{l}\text { C-section }(\mathrm{n}=79) \\
\begin{array}{l}\text { C-section and vaginal } \\
\text { birth }(\mathrm{n}=25)\end{array}\end{array}$ & $60(75.9)$ & $7(8.9)$ & $12(15.2)$ \\
\hline
\end{tabular}

Note: $(n=104)$.

\section{DISCUSSION}

The results indicate that, at home, the obstetric practice is consistent with the scientific evidence. However, some professionals still performed non-recommended interventions. It should be noted that the study population has a specific profile, different from that of the public Unified Health System (Sistema Único de Saúde - SUS) and, in general, the professionals who assisted home births sought to implement good practices during labor, delivery and birth. The environment favored the freedom to choose the delivery position and the opportunity to undergo vaginal delivery, even after a previous cesarean section, results that differ from the Brazilian hospital care.

Given the lack of publications of national data on home care, the findings of this study are also discussed with those performed in Brazilian vaginal birth centers (VBC), and with studies conducted in countries where, in most of them, home births are part of the health system, a reality that is different from Brazil.

The women who chose a PHB had a high level of education, a result similar to other Brazilian studies ${ }^{(8-12)}$. However, they were younger when compared to those of international studies $^{(1-3,13-14)}$. Women's high level of education shows that this is a people with unique characteristics, with access to information, who questions the current hegemonic model and seeks a place for the delivery that meets their expectations, in the same way as the women assisted in VBC, because care is less interventional than in the hospital ${ }^{(7)}$. However, most patients of VBC have low levels of education $^{(15-17)}$. Women assisted at home showed high compliance with prenatal care, which was also observed in a study carried out in a $\mathrm{VBC}^{(15)}$ and at home ${ }^{(10)}$.

The fact that women are younger can be explained by the study population, made up mainly of primiparous women, similar to other studies conducted in $\mathrm{Brazil}^{(8-12)}$. It is emphasized that this is virtually the only data that differs from most international studies, since multiparous women are the ones that opt more for the $\mathrm{PHB}^{(1-4,13-14,18)}$. The choice of $\mathrm{PHB}$ by 
Brazilian women, already in the first gestation, may be due to the desire for freedom and autonomy to participate in the process of delivery and birth of their child and the search for a less interventionist assistance in a welcoming environment, besides avoiding to undergo an unnecessary cesarean section $^{(12,19-20)}$. It is noteworthy that women with a previous cesarean section also opted for $\mathrm{PHB}$, as has already been pointed out in other studies conducted in Brazil ${ }^{(8-9)}$, which may demonstrate the dissatisfaction with this procedure. This finding is similar to that reported in other countries ${ }^{(13,21)}$, and these percentages may be due to protocols that discourage these women from being assisted at home $\mathrm{e}^{(1,4,14)}$.

Regarding the practices adopted during labor, most women had spontaneous rupture of the membranes or remained with an intact sac until the expulsive period, unlike the high percentages of amniotomy performed in hospitals $(40.7 \%)^{(7)}$ and in some VBC (ranging from $53.3 \%$ to $71.3 \%)^{(15-17)}$ to accelerate the evolution of labor ${ }^{(7)}$.

The use of oxytocin prior to birth should occur only in a hospital environment, since the effects of this drug cannot be controlled, which may even lead to the need for an emergency cesarean section ${ }^{(22)}$. Even so, some home-assisted women were given oxytocin during labor and delivery. Although inappropriate, its use is still in contrast with the high rate of oxytocin in women with habitual obstetric risk in hospitals $(38.2 \%)^{(7)}$ and $\mathrm{VBC}$ (ranging from $23.6 \%$ to $31 \%)^{(15-17)}$. Although contraindicated, including in WHO recommendations ${ }^{(22)}$ since 1996 , the Kristeller's maneuver was performed on a woman assisted at home. In Brazil, this maneuver is performed in more than one third of the women assisted in the hospitals $(37.3 \%)^{(7)}$. Most of the studies performed in VBC do not provide data about this maneuver; thus, it is not clear whether this practice has been abolished or whether it has been performed ${ }^{(16-17)}$.

In this study, no woman assisted at home was submitted to episiotomy, a finding that was totally discrepant with the rate of this intervention in Brazilian women who are assisted in the hospitals (56.1\%), which is even higher among primiparous women $(74.7 \%)^{(7)}$. In $\mathrm{VBC}$, this rate ranges from $7.2 \%$ to $25.7 \%$ of women ${ }^{(15-17)}$.

A few women who underwent vacuum extraction were assisted by obstetric physicians. It should be noted that, in Brazil, this procedure can only be performed by these professionals, who have legal protection.

Women who give birth at home and in VBC choose verticalized positions, and may assume a range of modalities, as pointed out in other Brazilian studies ${ }^{(8,15)}$, as well as the possibility of vertical birth in water ${ }^{(9-10)}$. This freedom of position differs greatly from the Brazilian hospital reality, in which virtually all women of usual obstetric risk give birth in a lithotomy position ${ }^{(7)}$. Women's choice to give birth at home and in VBC may be motivated by having more autonomy.

Many women in the present study had the opportunity to give birth in water, similar to other studies conducted in Brazil $^{(9-10)}$, and higher than in a study conducted in Australia $(52 \%)^{(18)}$ and Iceland (39.1\%) $)^{(23)}$. In Brazil, the prevalence of hospital vaginal deliveries in the water is poorly known, only one study pointed out a prevalence of $13.7 \%$ in a maternity of a supplementary sector ${ }^{(24)}$.

Preservation of perineal integrity, $2^{\text {nd }}$ degree laceration rate, and laceration suture were similar to those of national studies $^{(8-10)}$. Moreover, most lacerations were not sutured, following a tendency to adopt natural healing, which seems to contribute to the reduction of pain ${ }^{(25)}$. However, more evidence is needed to support this practice ${ }^{(26)}$. The rate of $3^{\text {rd }}$ and $4^{\text {th }}$ degree lacerations was equivalent to that of other national studies $^{(8-10)}$ and below the rate of other countries ${ }^{(3,10,27)}$.

The transfer rate was similar to that of two Brazilian studies $^{(8-9)}$ and was higher than a recent one $e^{(10)}$; however, it remains within the range indicated in international studies $^{(2-3,13,28)}$. In countries where there is a reference system, this rate is higher ${ }^{(29)}$, different from Brazil, which does not have a formalized reference flow. The rates of transfer of puerperal women and newborn infants were also reduced, as in other Brazilian $^{(8-9)}$ and international ${ }^{(13,18)}$ studies. In home care, the physiology of the process is respected, and few interventions are used, which may have contributed to the low neonatal transfer rate in this study.

Another finding worth mentioning is the cesarean section rate of the total number of women who had labor started at home (9\%), far below the Brazilian reality ${ }^{(6-7)}$, which shows that the chance of having a vaginal birth in this environment is greater. In other countries, the rate of $\mathrm{C}$-section in women who opted for the home environment is even lower than that of the current study ${ }^{(1-3,13,18)}$.

In addition, $80.8 \%$ of women with a previous $\mathrm{C}$-section gave birth at home, a higher percentage than in another Brazilian study ${ }^{(9)}$, but similar to international rates ${ }^{(13,21)}$. However, this is very different from the Brazilian hospital rate, of $14.8 \%$ of vaginal deliveries in women with a previous C-section ${ }^{(30)}$. In Brazil, there is no protocol for home care; thus, the teams decide whether or not to include women with a previous $\mathrm{C}$-section in their care protocol, and the inter-delivery interval.

The greatest limitation of the present study is the fact that it was not possible to calculate a sample that would make the generalization of the results possible, because, in Brazil, SINASC does not differentiate whether the deliveries occurring in a home environment were planned or not. Thus, the study has no sample power to discuss the maternal and neonatal outcomes of the PHB, but only to describe how obstetric practices occur in this place of birth. In addition, there may be a bias in data collection, since the professionals' participation was voluntary, with the use of the snowball technique, generating the inclusion of professionals from the same social network.

Finally, it is also not possible to be absolutely certain that all the assistance performed by registered professionals during the study period were included in the database, and that all interventions were recorded, causing an information bias. However, it should be noted that this is the first descriptive study with prospective data collection of childbirth care provided at home in a planned way, in the Northeast, Centerwest, Southeast and South regions of Brazil. 


\section{CONCLUSION}

At home, women experienced high rates of vaginal birth, with freedom of choice of delivery position, including the possibility of delivery in the water; they underwent few interventions during labor and delivery, and there was a low transfer rate before and after the delivery. Nonetheless, some interventions, such as Kristeller's maneuver and the use of oxytocin, contrast with scientific evidence and may risk maternal and neonatal health. A low rate of cesarean sections in the studied sample stands out, as well as a high number of women with previous cesarean sections who had vaginal delivery.
This research reveals that qualified professionals from different backgrounds who assist at home work autonomously, mainly in teams, developing good practices in childbirth care, and can act as multipliers of this expertise in care and teaching. However, it is imperative that further research be conducted to assess maternal and neonatal safety in the PHB.

Finally, it can be stated that women assisted by qualified professionals, as recommended by the $\mathrm{WHO}$, are receiving care that is consistent with the scientific evidence and the main findings of internationally published population-based studies produced in countries where home practice is largely supported by public policies.

\section{RESUMO}

Objetivo: Descrever as práticas obstétricas nos partos domiciliares planejados, assistidos por profissional qualificado, no Brasil. Método: Estudo descritivo, com dados coletados em banco on-line, alimentado por 49 profissionais de dezembro de 2014 a novembro de 2015 , no qual a população-alvo foi as mulheres e os recém-nascidos atendidos no parto domiciliar. Os dados foram analisados por estatística descritiva. Resultados: Foram incluídas 667 mulheres e 665 neonatos. A maioria das mulheres pariu em casa (84,4\%), em posição não litotômica $(99,1 \%)$, nenhuma foi submetida à episiotomia, 32,3\% tiveram períneo íntegro e 37,8\% tiveram laceração de $1^{\circ}$ grau, algumas foram submetidas à amniotomia $(5,4 \%)$, ocitocina $(0,4 \%)$ e manobra de Kristeller $(0,2 \%), 80,8 \%$ das mulheres com cesárea prévia tiveram parto domiciliar. A taxa de transferência de parturientes foi de 15,6\%, de puérperas foi de 1,9\%, e de neonatos foi de 1,6\%. A taxa de cesárea nas parturientes que iniciaram o acompanhamento domiciliar foi de 9,0\%. Conclusão: As práticas obstétricas adotadas estão em consonância com as evidências científicas, no entanto, ainda são realizadas intervenções desnecessárias. As taxas de cesárea e de transferência materna e neonatal são baixas. O domicílio pode ser uma opção de local de parto para mulheres que buscam um parto fisiológico.

\section{DESCRITORES}

Parto Domiciliar; Parto Humanizado; Enfermagem Obstétrica; Estudo Observacional.

\section{RESUMEN}

Objetivo: Describir las prácticas obstétricas en los partos domicilarios planificados, asistidos por profesional calificado, en Brasil. Método: Estudio descriptivo, con datos recogidos en banco en línea, alimentado por 49 profesionales de septiembre de 2014 a noviembre de 2015 , en el que la población blanco fue de mujeres y recién nacidos atendidos en parto domiciliario. Los datos fueron analizados por estadística descriptiva. Resultados: Fueron incluidas 667 mujeres y 665 neonatos. La mayoría de las mujeres parió en casa (84,4\%), en posición no litotómica (99,1\%), ninguna se sometió a la episiotomía, el 32,3\% mantuvieron el periné íntegro y el 37,8\% tuvieron laceración de $1^{\text {er }}$ grado, algunas fueron sometidas a la amniotomía (5,4\%), ocitocina (0,4\%) y maniobra de Kristeller (0,2\%), el 80,8\% de las mujeres con cesárea previa tuvieron parto domiciliario. El índice de transferencia de parturientes fue del 15,6\%, de puérperas fue del 1,9\% y de neonatos fue del 1,6\%. El índice de cesárea en las parturientes que iniciaron el acompañamiento domiciliario fue del 9,0\%. Conclusión: Las prácticas obstétricas adoptadas están en consonancia con las evidencias científicas, no obstante todavía se llevan a cabo intervenciones innecesarias. Los índices de cesárea y de transferencia materna y neonatal son bajos. El domicilio puede ser una opción de sitio de parto para mujeres que buscan un parto fisiológico.

\section{DESCRIPTORES}

Parto Domiciliario; Parto Humanizado; Enfermería Obstétrica; Estudio Observacional.

\section{REFERENCES}

1. Davis D, Baddock S, Tchng D, Pairman S, Hunter M, Benn C, et al. Planned place of birth in New Zealand: does it affect mode of birth and intervention rates among low-risk women? Birth. 2011;38(2):111-9. DOI: 10.1111/j.1523-536X.2010.00458.x.

2. Birthplace in England Collaborative Group. Perinatal and maternal outcomes by planned place of birth for healthy women with low risk pregnancies: the birthplace in England national prospective cohort study. BMJ. 2011;343:d7400. DOI: 10.1136/bmj.d7400.

3. Homer CS, Thornton C, Scarf VL, Ellwood DA, Oats JJN, Foureur MJ, et al. Birthplace in New South Wales, Australia: an analysis of perinatal outcomes using routinely collected data. BMC Pregnancy and Childbirth. 2014;14:206. DOI: 10.1186/1471-2393-14-206.

4. De Jonge, Geerts CC, Van Der Goes BY, Mol BW, Buitendijk SE, Nijhuis JG. Perinatal mortality and morbidity up to 28 days after birth among 743,070 low-risk planned home and hospital births: a cohort study based on three merged national perinatal databases. BJOG. 2014;122(5):720-8. DOI: 10.1111/1471-0528.13084

5. World Health Organization. Making pregnancy safer: the critical role of the skilled attendant: a joint statement by WHO, ICM and FIGO. Geneva: WHO; 2004.

6. Brasil. Ministério da Saúde; Secretaria de Ciência, Tecnologia e Insumos Estratégicos Departamento de Gestão e Incorporação de Tecnologias em Saúde. Diretriz Nacional de assistência ao parto normal [Internet]. Brasília; MS; 2017 [citado 2017 ago. 12]. Disponível em: http://portalarquivos.saude.gov.br/images/pdf/2017/marco/08/Diretrizes-Parto-Normal-resumida-FINAL.pdf

7. Leal MC, Pereira APE, Domingues RMSM, Theme Filha MM, Dias MAB, Nakamura-Pereira M, et al. Obstetric interventions during labor and childbirth in Brazilian low-risk women. Cad Saúde Pública. 2014;30 Suppl 1:S17-47. DOI: 10.1590/0102-311X00151513. 
8. Colacioppo PM, Koiffman MD, Riesco MLG, Schneck CA, Osava RH. Parto domiciliar planejado: resultados maternos e neonatais. Referência [Internet]. 2010 [citado 2013 set. 21];serlII(2):81-90. Disponível em: http://www.scielo.mec.pt/pdf/ref/vserllln2/serllln2a09.pdf

9. Koettker JG, Brüggemann OM, Dufloth RM, Knobel R, Monticelli M. Outcomes of planned home birth assisted by nurses, from 2005 to 2009, in Florianópolis, Southern Brazil. Rev Saúde Pública. 2012;46(4):747-50. DOI: 10.1590/S0034-89102012005000051

10. Koettker JG, Brüggemann OM, Knobel R. Maternal results from planned home births assisted by nurses from the Hanami team in the South of Brazil, 2002-2012. Texto Contexto Enferm. 2017;26(1):e3110015. DOI: 10.1590/0104-07072017003110015.

11. Feyer ISS, Monticelli M, Knobel R. Profile of couples who opt for home birth assisted by obstetric nurses. Esc Anna Nery Rev Enferm. 2013;17(2):298-305. DOI: 10.1590/S1414-81452013000200014

12. Lessa HF, Tyrrell MAR, Alves VH, Rodrigues DP. Information for the option of planned home birth: women's right to choose. Texto Contexto Enferm. 2014;23(3):665-72. DOI: 10.1590/0104-07072014000930013

13. Cheyney M, Bovbjerg M, Everson C, Gordon W, Hannibal D, Vedam S. Outcomes of care for 16,924 planned home births in United States: the Midwives Alliance of North America statistic project, 2004 to 2009. J Midwifery Womens Health. 2014;59(1):17-27. DOI: 10.1111/jmwh.12172

14. Hiraizumi Y, Suzuki S. Perinatal outcomes of low-risk planned home and hospital births under midwife-led care in Japan. J Obst Gynaecol. 2013;39(11):1500-4. DOI: 10.1111/jog12094

15. Silva FMB, Paixão TCR, Oliveira SMJV, Leite JS, Riesco MLG, Osava RH. Care in a birth center according to the recommendations of the World Health Organization. Rev Esc Enferm USP. 2013;47(5):1031-8. DOI: 10.1590/S0080-623420130000500004

16. Vogt SE, Diniz SG, Tavares CM, Santos NCP, Schneck CA, Zorzam B, et al. Características da assistência ao trabalho de parto e parto em três modelos de atenção no SUS, no Município de Belo Horizonte, Minas Gerais, Brasil. Cad Saúde Pública. 2011;27(9):1787-800. DOI: 10.1590/S0102-311X2011000900012

17. Scheneck CA, Riesco MLG, Bonadio IC, Diniz CSG, Oliveira SMJV. Maternal and neonatal outcomes at an alongside birth center and at a hospital. Rev Saúde Pública [Internet]. 2012 [cited 2017 Aug 15];46(1):77-86. Available from: http://www.scielo.br/scielo.php?script=sci_ arttext\&pid=S0034-89102012000100010\&lng=en\&nrm=iso\&tlng=en

18. Catling-Paul C, Coddington RL, Foureur MJ, Homer CS. Publicly funded homebirth in Austrália: a review of maternal and neonatal outcomes over 6 years. Med J Aust. 2013;198(11):616-20.

19. Frank TC, Pelloso SM. The perception of professionals regarding planned home birth. Rev Gaúcha Enferm. 2013;34(1):22-9. DOI: 10.1590/ S1983-14472013000100003

20. Sanfelice CFO, Shimo AKK. Home childbirth: progress or retrocession? Rev Gaúcha Enferm. 2014;35(1):157-60. DOI: 10.1590/19831447.2014.01.41356

21. Rowe R, Li Y, Knight M, Brocklehurst P, Hollowell J. Maternal and perinatal outcomes in women planning vaginal birth after caesarean (VBAC) at home in England: secondary analysis of the birthplace national prospective cohort study. BJOG. 2016;123(7);1123-32. DOI: $10.1111 / 1471-0528.13546$

22. World Health Organization. Care in normal birth: a practical guide. Geneva: WHO; 1996.

23. Halfdansdottir B, Smarason AK, Olafsdottir OA, Hildingsson I, Sveinsdottir H. Outcome of planned home and hospital births among lowrisk women in Iceland in 2005-2009: a retrospective cohort study. Birth. 2015;42(1):16-26. DOI: 10.1111/birt.12150

24. Scheidt TR, Brüggemann OM. Water birth in a maternity hospital of the supplementary health sector in Santa Catarina, Brazil: a crosssectional study. Texto Contexto Enferm. 2016;25(2):1-9. DOI: 10.1590/0104-07072016002180015.

25. Seijmonsbergen-Schermers AE, Sahami S, Lucas C, Jonge AD. Nonsuturing or skin adhesives versus suturing of the perineal skin after childbirth: a systematic review. Birth. 2015;42(2):100-15. DOI: 10.1111/birth.12166

26. Elharmeel SAM, Chaudhary Y, Tan S, Scheermeyer E, Hanafy A, Van Driel ML. Surgical repair versus non-surgical management of spontaneous perineal tears. Cochrane Database Syst Rev. 2011;(8):CD008534.

27. de Jonge A, Peters L, Geerts CC, van Roosmalen JJM, Twisk JWR, Brocklehurst P, et al. Mode of birth and medical interventions among women at low risk of complications: a cross-national comparison of birth settings in England and the Netherlands. PLoS One. 2017;12(7):e0180846. DOI: doi.org/10.1371/journal.pone.018084612(7)

28. Blix E, Kumle MH, Ingversen K, Huitfeldt AS, Hegaard HK, Ólafsdóttir ÓÁ, et al. Transfers to hospital in planned home birth in four Nordic countries: a prospective cohort study. Acta Obstet Gynecol Scand. 2016;95(4):420-8. DOI: 10.1111/aogs.12858

29. Blix E, Kumle M, Kjaergaard H, Oian P, Lindgren HE. Transfer to hospital in planned home births: a systematic review. BMC Pregnancy Childbirth. 2014.14:179. DOI: 10.1186/1471-2393-14-179

30. Domingues RMSM, Dias MAB, Nakamura-Pereira M, Torres JA, D'Orsi E, Pereira APE, et al. Process of decision-making regarding the mode of birth in Brazil: from the initial preference of women to the final mode of birth. Cad Saúde Pública. 2014;30 Suppl 1:S101-16. DOI: 10.1590/0102-311X00105113. 